\title{
EFFECTIVENESS OF GUIDED IMAGERY THERAPY ON REDUCING STRESS AMONG IT PROFESSIONALS
}

*Mrs. R. Ajitha Nancy Rani \& **Prof. V. Hemavathy

'To look behind or to look upfront is not as important as to look inside'

- Randolf Waldo Emerson

\begin{abstract}
:
IT careers are often characterized by hard work, long hours, stress and tight deadlines. The level of stress among IT professionals is high and it affects both the employer and the employee. The experimental study was conducted to determine the effectiveness of guided imagery to reduce the level of stress. Total 60 subjects were selected one group Pre Test - Post Test design was used. Evaluative research approach was used. Datas were collected by using structured questionnaire. Stress was measured in terms of stress scores. After administration of guided imagery the findings reveals that 34 (56.7\%) of subjects had mild stress 26 (43.3\%)of subjects had moderate stress and none of them had severe stress.
\end{abstract}

Key words: Effectiveness, Guided imagery therapy, stress, IT professionals.

\section{Introduction:}

Mental health as a continuum highlights the emotional wellbeing. Anderson (2001) states that Guided imagery is the use of one's imagination to promote mental and physical health. Arandelovic MilIC (2006) states that stress in IT profession have impact on both employer and the employee. Cooper (2008) examined that the employees reported commonly occurring symptoms of stress like decrease in energy, anxiety, muscle tension head ache, stomach upset, and insomnia. Debra van CA (2007) studied the stressful life of IT professionals and their coping mechanism. Barbara (2002) states that stress can manifest in variety of emotional, behavioural, and physical symptoms. Baider (2005) evaluate the effect of guided imagery in college students. Beck.Rawlins (2002) evaluated that stress, a common factor for working persons. Brooking,
Susan et al (2004) states that positive guided imagery can promote relaxation and reduce stress. Utay. J. Miller (2006) determined that stress reduction through coping mechanisms yield results. Doris. B. Payne (2006) determined the effect of guided imagery on patient with head ache. Elizabeth.M.et.al (2005) revealed that guided imagery as coping strategy for patients. Lalitha (2003) revealed the effects of guided imagery on stress.

\section{Objectives}

1. To determine the effectiveness of guided imagery to reduce the level of stress.

2. Association between post level of stress and selected demographic variables.

Materials and Methods

The experimental study was conducted on persons $(\mathrm{N}=60)$ including men and women of IT profession from an IT company in Chennai. One group Pre Test - Post Test design was used 
to evaluate the effectiveness of guided imagery therapy. Evaluative research approach was used. A structured interview stress assessment scale was developed and used to assess the effect of guided imagery therapy on the level of stress. Data was collected from the subjects. The level of stress was graded in 3 categories; the grades were mild, moderate, and severe.

\section{Grading of Stress Score}

\begin{tabular}{|c|c|}
\hline Level of stress & Scores \\
\hline Mild & $0-40$ \\
\hline Moderate & $41-80$ \\
\hline Severe & $81-120$ \\
\hline
\end{tabular}

The reliability co-efficient was calculated using Karl-Pearson's formula. After the pre- test, guided imagery therapy was administered to the subjects and the post test was conducted.

Key: $01-$ Pre Test level of stress, X - Guided imagery therapy, 02 - Post Test level of stress

\begin{tabular}{|c|c|c|c|}
\hline Group & $\begin{array}{c}\text { Pre } \\
\text { Test }\end{array}$ & Treatment & $\begin{array}{c}\text { Post } \\
\text { Test }\end{array}$ \\
\hline Experiment & $\mathrm{O} 1$ & $\mathrm{X}$ & $\mathrm{O} 2$ \\
\hline
\end{tabular}

\section{Results and Discussion}

Demographic findings revealed that among 60 samples of IT professionals, 13 (21.8\%) belonged to the age group of $25-35$ years. $16(26.5 \%)$ belonged to the age group of 36 - 40 years, 15 (25\%) belonged to the age group of 41 - 45 years, $16(26.7 \%)$ are above 45 years, $33(55 \%)$ were males, $27(45 \%)$ were females. $45(75 \%)$ were married $15(25 \%)$ were unmarried.

\section{Comparison between Pre Test \& Post Test on stress among IT Professionals before and after guided imagery therapy.}

\begin{tabular}{|c|c|c|c|c|c|}
\hline SI & Level of & \multicolumn{2}{|c|}{ Pre Test } & \multicolumn{2}{c|}{ Post Test } \\
\cline { 3 - 6 } No & Stress & Nos & $\%$ & Nos & \% \\
\hline 1 & MILD & 8 & 13.3 & 34 & 56.7 \\
\hline 2 & MODERATE & 42 & 70 & 26 & 43.3 \\
\hline 3 & SEVERE & 10 & 16.7 & 0 & 0 \\
\hline
\end{tabular}

Results of the study revealed that the stress level is high before administration of guided imagery therapy. Level of significance was set as $\mathrm{P}<$ 0.001. Among 60 samples of IT Professionals, 8 (13.3\%) had mild stress, 42 (70\%) had moderate stress, $10(16.7 \%)$ of them had severe stress. After administration of guided imagery therapy, $34(56.7 \%)$ had mild stress, $26(43.3 \%)$ had moderate stress and none of them had severe stress.

The mean of overall stress is 26.9 and the standard deviation is 8.3 , ' $t$ ' value of stress is 16.3 and the level of significance is $\mathrm{P}<0.001$. The inference ' $t$ ' value of post - test (16.3) was highly significant which reveals the effectiveness of guided imagery therapy. There was association between post level of stress and selected demographic variable such as age, sex, education, marital status, occupation, monthly income, residential place, social support, and type of family.

The result of this study indicates that the stress level of IT professionals was reduced after guided imagery therapy

\section{Conclusion}

The stress level of IT professionals was significantly lower in post-test than the pre- test. Guided imagery was found to be effective in reducing the stress. The post test scores supports that there is improvement in the level of stress after administration of guided imagery therapy. 


\section{Bibliography}

Anderson (2001) the effects of guided imagery therapy on reported change in normal adults, Journal of Therapy. Vol 36.

Arandelovic M IIic, Stress in work place possible prevention, FactaUniverstitatis, Seris.

Barbara (2002) Psychiatric Mental Health Nursing, Philadelphia, C.V Mosby Company.

Baider.L (2004) Progressive muscle relaxation and Guided imagery, Journal of General Hospital Psychiatry, Vol. 16, Issue 5.

Beck. Rawlins Mental Health Psychiatric Nursing, Mosby Publication

Brooking, Susan et.al., (2004) Text book of psychiatry Church Chill Living Stone Publishers.
Debra van, (2006) A Meta analysis of the effect of Guided imagery practice outcome, Journal of Holistic Nursing, Vol 22.

Doris. B. Payne A. Psychiatric Mental Health Nursing. $2^{\text {nd }}$ Edition, Toppan Company Private Limited, Singapore.

Elizabeth M.et.al, (2006) Foundation of Psychiatric Mental Health Nursing $5^{\text {th }}$ Edition Saunders Elisevier Publication.

Glen.O.Gobbard, (2000). Treatments of Psychiatric Disorder. $2^{\text {nd }}$ Edition, Volume 1, Jaypee Brothers Ltd, New Delhi.

MatharMohideen. N, (2008) Stress Management, Journal of Nightingale Nursing Times. Vol 7. Issue 7.

Utay, J.Miller (2006) Guided imagery as an effective therapeutic technique; a brief review of its history and efficacy research, Journal of Instructional Psychology. 